\section{References}

${ }^{1}$ Coffman JD, Davies T. Vasospastic disorders: a review. Prog Cardiovasc Dis $1975 ; 18: 123-46$.

2 Halperin JL, Coffman JD. Pathophysiology of Raynaud's disease. Arch Intern Med 1979;139:89-92.

Halpern A, Kuhn PH, Shaftel HE, et al. Raynaud's phenomenon and serotonin. Angiology 1960;11:151-67.

4 Allen EV, Brown GE. Raynaud's disease: a critical review of minor requisites for diagnosis. Am $\mathcal{F}$ Med Sci 1932;183:187-200.

5 Stranden E, Grip A. Fotopletysmografi. Tidsskr. Nor Laegeforen 1981 ;101, 17-18:1071-3.

${ }^{6}$ Hertzmann AB. Photoelectric plethysmography of the fingers and toes in man Proc Soc Exp Biol Med 1937;37:529-34.

${ }^{7}$ Wenting GJ, Man in't Veld AJ, Woittiez AJ, Boomsma F, Schalekamp MADH. Treatment of hypertension with ketanserin, a new selective 5-HT ${ }_{2}$ receptor antagonist. $\mathrm{Br}$ Med f 1982;284:537-9.

${ }^{8}$ Wintrobe MM, Thorn GW, Adams RD, et al. Principles of internal medicine. 6th ed. New York: McGraw-Hill, 1970.
${ }^{9}$ Van Nueten JM, Janssen PAJ, Ridder WD, Vanhouette PM. Interaction between 5-hydroxytryptamine and other vasoconstrictor substances in the isolated femoral artery of the rabbit; effect of ketanserin ( $R 41468$ ). Eur F Pharmacol 1982;77:281-7.

11) Janssen PAJ. The pharmacology of specific, pure and potent serotonin $5-\mathrm{HT}_{2}$ or $\mathrm{S}$-antagonists. In: Yoshida $\mathrm{H}$, Hagihara $\mathrm{Y}$, Ebashi $\mathrm{S}$, eds. Advances of pharmacology and therapeutics II. Vol 4. Oxford, New York: Pergamon Press, 1982:21-33.

${ }^{11}$ Zahavi J, Hamilton WAP, O'Reilly MJG, Leyton J, Cotton LT, Kakkar VV. Plasma exchange and platelet function in Raynaud's phenomenon. Thromb Res 1980;19:77-88.

1.2 Blunt RJ, Porter JM. Raynaud syndrome. Semin Arthritis Rheum 1981; 10:282-308.

${ }^{13}$ De Cree J, Leempoels J, Geukens H, De Cock W, Verhagen H. The antihypertensive effects of ketanserin ( $R$ 41468), a novel 5-hydroxytryptamine-blocking agent, in patients with essential hypertension. Cli Sci $1981 ; 61: 473-6 S$.

(Accepted 15 fuly 1982)

\title{
Pericapillary fibrin in the ulcer-bearing skin of the leg: the cause of lipodermatosclerosis and venous ulceration
}

\author{
K G BURNAND，I WHIMSTER，A NAIDOO，N L BROWSE
}

\begin{abstract}
Forty-one biopsy specimens, taken from the ulcer-bearing skin of 41 legs of 21 patients attending the varicose vein clinic, were selectively stained for fibrin with phosphotungstic acid haematoxylin before being blindly assessed. Layers of fibrin were found surrounding the dermal capillaries in all 26 legs with lipodermatosclerosis. None of the specimens from the 15 legs with clinically normal skin contained fibrin. There was also an increased number of dermal capillaries cut in cross section per high powered field in 24 of the 26 legs with lipodermatosclerosis compared with two of the 15 legs with normal skin $(p<0.001)$. The mean reduction in foot vein pressure during exercise was significantly less in the 26 limbs with pericapillary fibrin than in the other 15 limbs $\left(p<10^{-6}\right)$. Lipodermatosclerosis is synonymous with pericapillary fibrin deposition and is associated with, and probably secondary to, both a persistently raised venous pressure and an increase in the size of the dermal capillary bed. This extravascular deposition of fibrin probably stimulates tissue fibrosis and blocks the diffusion of oxygen to the overlying epidermis, producing cellular death and venous ulceration.
\end{abstract}

\section{Introduction}

The mechanism by which venous disorders of the leg produce ulceration around the ankle is unknown. Ulceration is the final event in a well-recognised series of changes in the skin and subcutaneous tissues. The first changes are cutaneous pigmentation, mild ankle oedema, and the appearance of dilated subdermal venules. Later the skin and subcutaneous fat becomes thickened and hard. Since the tissues are often red and tender

Departments of Surgery, Physiology, and Dermatology, St Thomas's Hospital, London SE1

K G BURNAND, MS, FRCs, assistant director, department of surgery

I WHIMSTER, MB, MRCPATH, reader in pathology of the skin (Dr Whimster died in 1979)

A NAIDOO, medical student

N L BROWSE, MD, FRCS, professor of surgery they are mistakenly thought to be infected or to be the site of superficial thrombophlebitis. At this stage minor trauma will cause an ulcer. If ulceration does not occur the skin and fat contract and the patient develops a tight narrow gaiter of hard skin. We prefer to call this whole process "lipodermatosclerosis" rather than give each clinical phase a separate name.

In a series of experiments designed to elucidate the underlying cause of these changes we have shown that legs with poor calf pump function, as shown by the failure of exercise to reduce foot vein pressure, have an increased number of capillary loops within the ulcer-bearing skin. ${ }^{1}$ Confirmation that this was a causal relation was obtained from an animal study in which an increase in the venous pressure produced a similar increase in the size of the capillary bed of the calf skin. ${ }^{2}$

Increasing the capillary pressure opens the intercellular endothelial pores and increases capillary permeability. ${ }^{3}{ }^{4}$ Studies in animals showed that the high intraluminal venous pressure and increased endothelial surface area available for exchange did not change the rate at which albumin and sodium escaped from the vascular compartment into the subcutaneous tissue fluid, but fibrinogen, a much larger molecule, accumulated significantly faster in the tissue fluid around the enlarged capillary bed. ${ }^{2}$

The object of this study was to determine whether chronic venous hypertension and lipodermatosclerosis were associated with the accumulation of fibrinogen-fibrin in the perivascular interstitial spaces of human limbs.

\section{Patients and methods}

We studied 42 legs of 21 patients ( 10 men and 11 women) without venous ulceration who were attending our varicose vein clinic. The limbs were examined for evidence of superficial, communicating, and deep-vein incompetence. The presence of liposclerosis was noted. Foot vein pressure during rest and exercise was measured successfully in 41 of the 42 legs. The foot veins of one limb could not be cannulated so this limb was excluded from the study. The method of pressure measurement has been described in detail elsewhere. ${ }^{5}$ The results for each leg were obtained by expressing the fall in pressure $(\mathrm{mm} \mathrm{Hg})$ as a percentage of the resting pressure. Bipedal phlebograms were obtained from all patients using the method described by Lea Thomas. ${ }^{6}$

The results of the clinical examination and phlebography were combined to classify all limbs into one of four categories, each 
reflecting an increasing degree of chronic venous hypertension: (a) normal limbs (not excluding those with occasional minor varicosities); (b) limbs without liposclerosis but with saphenous vein (long or short) incompetence and normal deep veins; (c) limbs with liposclerosis, saphenous vein (long and short) incompetence, and normal deep veins; and $(d)$ limbs with liposclerosis and damaged deep veins.

Assessment of extravascular fibrin-Small biopsy specimens of skin ( $5 \mathrm{~mm} \times 10 \mathrm{~mm}$ ellipses) were taken from the medial side of the calf of all 41 legs $7.5 \mathrm{~cm}$ vertically above the medial malleolus, a point which invariably coincided with the most severe liposclerosis when this was present. All the biopsies were stained with phosphotungstic acid haematoxylin (PTAH), which colours fibrin and related substances blue. The sections were then examined by one observer (IW), who was unaware of the other findings. Each specimen was reported as showing fibrin present or absent on this examination. The number of capillary vessels cut in cross section in each highpowered field was also assessed in arbitrary units, as previously described. ${ }^{1}$ Biopsy specimens from two limbs with liposclerosis were examined for fibrin by an immunofluorescent technique using a rabbit-raised antifibrin ${ }^{7}$ and also studied with transmission electronmicroscopy. ${ }^{8}$

The study was approved by the hospital ethical committee and all patients gave their informed written consent to the procedure.

\section{Results}

Clinical phlebographic categories and venous hypertension-Ten legs were normal; six legs had no liposclerosis but had saphenous vein incompetence with normal deep veins; five legs had liposclerosis, saphenous vein incompetence, and normal deep veins; and 20 legs had liposclerosis and phlebographic evidence of damaged deep veins. Thus 26 of the 41 limbs had liposclerosis. The mean percentage reductions in foot vein pressure during exercise in these four groups were: $58 \%, 53 \%, 35 \%$, and $12 \%$ respectively. These results confirmed the relationship between the physical signs and phlebographic assessment on the one hand and calf pump inefficiency on the other.

Pericapillary fibrin-A layer of fibrin (blue fibrillary material on PTAH staining) was seen surrounding the dermal capillaries in 26 of the biopsy specimens while no fibrin was seen in the other 15 . Two specimens that showed the blue-staining pericapillary material on the PTAH sections were tested with an immunofluorescent antibody to fibrin. Both were found to have a halo of fluorescence around individual capillaries corresponding to the area that stained blue with PTAH, confirming the presence of fibrin. Electronmicroscopic examination of specimens from the same patients showed a material with the fibrillary structure of fibrin around the capillaries. The biopsy specimens of all 26 legs with liposclerosis contained pericapillary fibrin, while those from the 15 legs without liposclerosis did not contain pericapillary fibrin $\left(p=1.58 \times 10^{-11}\right.$, Fisher's exact test). Twenty-four of the 26 specimens that contained pericapillary fibrin also showed an increased number of dermal capillaries cut in cross section, while 13 of the 15 without fibrin had a normal number of capillaries $\left(\chi^{2}=25.57 ; p<0.001\right)$.

Fibrin and calf-pump efficiency-The mean reduction of foot vein pressure during exercise in the 26 legs with pericapillary fibrin was $17 \cdot 2 \pm 18 \%$ (SD), which was significantly less than the mean reduction of $54.6 \% \pm 20$ in the 15 limbs without liposclerosis $\left(t=6.006 ; \mathrm{p}<10^{-6}\right)$.

\section{Discussion}

These studies show that fibrin is present in the skin of the ulcer-bearing area of the legs of all patients with lipodermatosclerosis. The fibrin is laid down as a cuff around the enlarged dermal capillary bed. We have previously presented experimental evidence that chronic venous hypertension increases the leakage of large molecules into the tissue spaces, ${ }^{2}$ and so we postulate that this accumulation of fibrin within the tissues is the result of greater quantities of fibrinogen escaping through capillary pores which are enlarged by the raised venous pressure. ${ }^{34}$ Since the fibrinolytic activity of the blood and the tissues is deficient in patients with lipodermatosclerosis, ${ }^{9}$ any fibrinogen which is converted to fibrin in the interstitial spaces is less likely to be broken down or reabsorbed.

The high venous oxygen tensions found in the venous blood of ulcerated limbs ${ }^{10-13}$ could be explained if it were shown that fibrin prevents the passage of oxygen into the tissues, so turning the capillaries into physiological shunts. The Appendix contains the details of a simple experiment which shows that a $1-\mathrm{mm}$ layer of fibrin reduces the diffusion of oxygen across a layer of water by a factor of 25 . We therefore suggest that the pericapillary layer of fibrin acts as a diffusion barrier, leading to local tissue ischaemia, which is manifested as lipodermatosclerosis or ulceration.

If fibrin deposition can be reduced at an early stage, before it starts to kill tissue or stimulates irreversible fibrosis, venous ulceration may be prevented. This may be accomplished by surgical restoration of calf-pump efficiency, by the use of elastic compression, or by the use of drugs which enhance tissue fibrinolysis. ${ }^{14}$

\section{Appendix}

The permeability of a $1-\mathrm{mm}$ thick commercial fibrin membrane (Ethicon Ltd) was tested for air, oxygen, and carbon dioxide in a specially designed diffusion chamber. A fugacity gradient was produced for each gas to maximise diffusion velocity through the aqueous media, and gas movement was measured by the displacement velocity of a meniscus formed within a volumetric capillary tube connected to the gas reservoir. Each gas was tested five times after initial measurements conducted with air diffusion and no membrane. The diffusion capacity of the fibrin was obtained by dividing the rate of gas diffusion in millilitres standard temperature and pressure in dry air per minute by the pressure difference across the membrane in $\mathrm{mm} \mathrm{Hg}$.

The diffusion capacity of both oxygen and air with no membrane in place was $5.04 \times 10^{-5} \mathrm{~cm}^{3} / \mathrm{min} / \mathrm{mm} \mathrm{Hg}$, which fell to $0.228 \times 10^{-5}$ $\mathrm{cm}^{3} / \mathrm{min} / \mathrm{mm} \mathrm{Hg}$ when the membrane was inserted. The diffusion of carbon dioxide $\left(0.699 \times 10^{-5} \mathrm{~cm}^{3} / \mathrm{min} / \mathrm{mm} \mathrm{Hg}\right)$ was not affected by the membrane and was very similar to the diffusion capacity of carbon dioxide through the alveolar membrane $\left(0.598 \times 10^{-5} \mathrm{~cm}^{3} / \mathrm{min} /\right.$ $\mathrm{mm} \mathrm{Hg}$ ).

A sheet of fibrin appears to allow carbon dioxide to pass through it $\vec{\oplus}$ relatively freely but is relatively impermeable to the passage of oxygen.

\section{References}

i Burnand KG, Whimster IW, Clemenson G, Lea Thomas M, Browse NL. The relationship between the number of capillaries in the skin of the venous ulcer bearing area of the lower leg and the fall in foot vein pressure during exercise. Br $\mathcal{F}$ Surg $1981 ; 68: 297-300$.

2 Burnand KG, Clemenson G, Whimster I, Gaunt J, Browse NL. The effect of sustained venous hypertension in the skin capillaries of the canine hind limb. Br ₹ Surg 1982;69:41-4.

${ }^{3}$ Shirley HH, Wolfram CG, Wasserman K, Mayerson HS. Capillary permeability to macromolecules: stretched pore phenomenon. $\mathcal{f}$ Physio 1957;190:189-93.

4 Pietra GG, Szidon JP, Leventhal MM, Fishman AP. Haemoglobin as a tracer in haemodynamic pulmonary oedema. Science 1969;166:1643-6.

5 Burnand KG, O'Donnell TF, Lea Thomas M, Browse NL. The relative importance of incompetent communicating veins in the production of varicose veins and venous ulcers. Surgery 1977;82:9-14.

${ }^{6}$ Lea Thomas M. Phlebography. Arch Surg 1972;104:145-50.

7 Cormane RH, Szabo E, Hauge LS. Immunofluorescence of the skin: The interpretation of the staining of blood vessels and connective o tissue aided by new techniques. Br F Dermatol 1970;82:suppl 5:26-43.

${ }^{8}$ Rhodin JAG. Ultrastructure of mammalian venous capillaries, venules and small collecting veins. $\mathcal{F}$ Ultrastruct Res $1969 ; 25: 425-500$.

${ }^{9}$ Browse NL, Jarrett PEM, Morland M, Burnand KG. Treatment of liposclerosis of the leg by fibrinolytic enhancement a preliminary report. Br Med f 1977 ;ii :434-5.

10 Blalock A. Oxygen content of blood in patients with varicose veins. Arch Surg 1929;19:898-905.

11 Holling HE, Beecher HK, Linton RR. Study of the tendency to oedema formations associated with incompetence of the valves of the communicating veins of the leg. Oxygen content of the blood contained in varicose veins. $\mathcal{f}$ Clin Invest 1938;17:555-61.

12 Piulacks P, Vidal Barraquer F. Pathogenic study of varicose veins. Angiology 1953;4:59-100.

${ }^{13}$ Fontaine R. Remarks concerning venous thrombosis and its sequelae Surgery 1957;41:6-17.

14 Burnand KG, Clemenson G, Morland M, Jarrett PEM, Browse NL. Venous lipodermatosclerosis: treatment by fibrinolytic enhancement and elastic compression. $\mathrm{Br} \mathrm{Med} \mathcal{F}$ 1980;280:7-11.

들

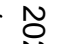

\section{. . 然 㝘

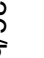

.

,

南

.

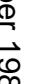

.

.

䅰

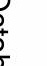

\section{.}

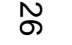
స్ట 